\section{November 2001}

Manchester Medical Society Joint Meeting with the BDA and Symposium: 'Let's be articulate about the masticatory system' Date: 27.11.01

Venue: Manchester Dental Education Centre (MANDEC)

Contact: Miss Fiona Lamb, Manchester

Medical Society, c/o John Ryland's University, Oxford Road, Manchester. M13 9PP.

Tel: +44 (0)161 2736048

Fax: +44 (0)161 2728046

E-mail: admin@mcr-med-society.u-net.com

Website: www.mms.org.uk

\section{December 2002}

Faculty of Dental Surgery Study Day: Infection Control

Date: 07.12.02

Venue: The Royal College of Surgeons of England, London

Contact: Fatima Bulbulia, Administrator,

Faculty of Dental Surgery, Royal College of Surgeons of England, 35-43 Lincoln's Inn

Fields, London. WC2A 3PE.

Tel: +44 (0)2078696815

Fax: +44 (0)2078696816

E-mail:mfds@rcseng.ac.uk

Royal Society of Medicine Odontological Section Meeting: A Glimpse of Tomorrow, Part II

Date: 10.12 .02

Venue: The Royal Society of Medicine Contact: Lochana Nanayakkara, Secretary Elect, Section of Odontology, The Royal Society of Medicine, 1 Wimpole Street, London, W1G OAE.

Tel: +44 (0)207 2903934

Fax: +44 (0)2072902989

E-mail: Odontology@rsm.ac.uk

\section{January 2002}

The Arab Health Series Exhibition and Conference

Date: $26.01 .02-29.01 .02$

Venue: Dubai World Trade Centre.

Contact: Elaine Nettleton, PR Manager,

IIR Exhibitions, PO Box 28943, Dubai.

Tel: 97143365161

Fax: 97143360137
E-mail: enettleton@iir-dubai

The Royal Society of Medicine Odontological Section Meetings: A Glimpse of Tomorrow, Part III

Date: 14.01 .02

Venue: The Royal Society of Medicine, London

Contact: Lochana Nanayakkara, Secretary

Elect, Section of Odontology, The Royal

Society of Medicine, 1 Wimpole Street,

London, W1G OAE.

Tel: +44 (0)2072903934

Fax: +44 (0)2072902989

E-mail: Odontology@rsm.ac.uk

\section{February 2002}

The Royal Society of Medicine Odontological Section Meeting: A Glimpse of

Tomorrow, Part IV

Date: 11.02 .02

Venue: The Royal Society of Medicine,

London

Contact: Lochana Nanayakkara, Secretary

Elect, Section of Odontology, The Royal

Society of Medicine, 1 Wimpole Street,

London, W1G OAE.

Tel: +44 (0)2072903934

Fax: +44 (0)207290 2989

E-mail: Odontology@rsm.ac.uk

Barbados Dental Association 14th Annual Mid-Winter Meeting

Date: 18.02.02-23.02.02

Venue: Accra Beach Hotel

Contact: Dr Colin Wynne-Davies, 9

Crofton Road, Orpington, Kent. BR6 8AE.

Tel: +44 (0)1689 821217

E-mail: cwynnedavies@cs.com

Website: www.barbadosda.org

\section{March 2002}

The Royal Society of Medicine Odontological Section Meeting: A Glimpse of Tomorrow, Part V

Date: 18.03 .02

Venue: The Royal Society of Medicine, London

Contact: Lochana Nanayakkara, Secretary

Elect, Section of Odontology, The Royal

Society of Medicine, 1 Wimpole Street,
London, W1G OAE.

Tel: +44 (0)2072903934

Fax: +44 (0)2072902989

\section{April 2002}

The Royal Society of Medicine Odontological Section Meeting: A Glimpse of

Tomorrow, Part VI

Date: 22.04 .02

Venue: The Royal Society of Medicine, London

Contact: Lochana Nanayakkara, Secretary

Elect, Section of Odontology, The Royal

Society of Medicine, 1 Wimpole Street, London, W1G OAE.

Tel: +44 (0)2072903934

Fax: +44 (0)2072902989

\section{May 2002}

The British Society for Restorative Dentistry Spring Scientific Meeting

Date: 10.05.02-11.05.02

Venue: The Haven Hotel, Sandbanks, Poole, Dorset.

Contact: Janet Harlow, Turner Dental School, Higher Cambridge Street, Manchester, M15 6FH.

Tel/Fax: +44 (0)1612756797

E-mail: janet.Harlow@man.ac.uk

\section{June 2002}

108th Meeting of the American Dental

Society of Europe

Date: 18.06.02-21.06.02

Venue: Prague, Czech Republic

Contact: Dr Paul O'Neilly, 5a Oriental

Road, Woking, Surrey, GU22 7AH.

Tel/Fax: +44 (0)1483 728411

E-mail: p.oneilly@dial.pipex.com

Website: www.adse.co.uk

\section{September 2002}

Congress 2002 for Cranio-Maxillofacial

Surgery

Date: 03.09.02-07.09.02

Venue: Münster, Germany

Contact: ABC Congress Service, Ariane Minarik, Arberstr. 18, D-81679. München, Germany.

Tel: $+49(0) 8923115015$

Fax: $+49(0) 89263167$ 